\title{
Numerical Solution of Delayed SIR Model of Tuberculosis with Combination of Runge Kutta Method and Taylor Series Approach
}

\author{
Budi Halomoan Siregar ${ }^{1}$, Yulita Molliq Rangkuti ${ }^{2}$, Abil Mansyur ${ }^{3}$ \\ \{Budihalomoan2@gmail.com ${ }^{1}$, \\ yulitamlliq@unimed.ac.id²abilmpanjaitan@gmail.com $\left.{ }^{3}\right\}$ \\ Department of Mathematic, Faculty of Mathematics and Fundamental Science, Indonesia ${ }^{1}$, \\ Department of Computing, State University of Medan, Indonesia ${ }^{2,3}$
}

\begin{abstract}
In this paper, the implementation of fourth-order Runge Kutta method with Taylor series approach for solving Susceptible Infected Remove (SIR) Model withincluding to system of delay differential equation (DDEs). The method obtained approximate solutions of the model using constant step size. The DDEs will be treated in expantion of Taylor Series i.e. $y(t-\tau)=y(t)+\tau \frac{d y}{d t}$. Numerical results are presented to show that the method is suitable for solving the System of DDEs and also time delay give the effect to Infected and recovered populations for $\tau \geq 0$.
\end{abstract}

Keywords: Runge Kutta Method; Taylor Series; SIR Model; Time Delay.

\section{Introduction}

Tuberculosis (TB) continues to be a health problem in the world, especially in developing countries. Tuberculosis is the top ten most common infectious diseases in the world. In 2016, as many as 10.4 million people worldwide had contracted tuberculosis and 1.7 million of them died.

Indonesia, India, China, the Philippines, Pakistan, Nigeria and South Africa are seven developing countries that contribute 64 percent of the total spread of tuberculosis worldwide. Data from the World Health Organization (WHO) recently released in January 2018 states that the number of TB cases in Indonesia reached 1.6 million in 2016, with an estimated 100,000 deaths per year. Thus, there are 273 cases of death per day or 11 deaths every hour due to TB (Putra (2018)). The average discovery for the city of Medan in that month could be 1000 people suspect TB with sufferers of 150 to 200 people every month found. TB patients who have been found in the past six years reached 7,600 people. Those who recovered were 3,078 people. The rest, currently in the process of processing and there are also many who die as many as 35 people (Dani, 2017). From the data submitted by Dani, (2017), there is an increasing TB cases in Medan, thereforefinding a suitable mathematical model to control spread of TB disease is important.

Many researchers continue to build mathematical models for TB disease such as Zwerling et al., 2015, find new diagnoses, therapies, and develop algorithms to improve case discovery, diagnosis, and clinical management of patients with TB, making policies in making difficult decisions and choosing to use technology when working under heavy pressure. Then Taufik et 
al. (2015) developed a mathematical model of vaccinated TB disease with exogenous infection and found that disease-free eigen values were always negative, meaning that the stable model was symptomatically disease-free. Rangkuti et. al. (2014) have been constructed an mathematical model of TB, VSEIR, to analysis the stability and the dynamical VSEIR populations for $0 \leq \mathrm{t} \leq 25$. Iskandar et al. (2017) analyzed the stability of the mathematical model of SIR by adopting time delay during recuperation. The model was stabil.

Various numerical methodshave been solved SIR model. A more robust and intricate numerical technique is the Runge Kutta method (RK). This method is the most widely used one since it gives reliable starting values and is particularly suitable when the computation of higher derivatives is complicated Islam (2015).Based on provious statement, RK mothod will use to solve SIR model.

In skandar's paper, the solution of SIR with time delay numerically to show impact of time delay toward number of SIR populations.

\section{Sir Model With Time Delay}

The delay time in the model is described as the time needed by the virus that infects cells so that the virus develops, delays occur due to continuous treatment. In this paper the model of susciptible, infected and recovery (SIR) with time delay and without delay. This model was developed by Iskandar et al (2017) as

$$
\begin{gathered}
\frac{d S_{v}}{d t}=c \pi N+\gamma R-\frac{\beta_{V} S_{v} I}{N}-\mu \frac{S_{v}}{N} \\
\frac{d S_{T}}{d t}=(1-c) \pi N-\frac{\beta_{T} S_{T} I}{N}-\mu S_{T} \\
\frac{d I}{d t}=\frac{\beta_{V} S_{v} I}{N}+\frac{\beta_{T} S_{T} I}{N}-\mu I-\vartheta I(t-\tau)(3) \frac{d R}{d t}= \\
\vartheta I(t-\tau)-\mu R-\gamma R \\
N=S_{v}+S_{T}+E_{v}+E_{T}+I+R
\end{gathered}
$$

Where $\mathrm{N}$ as the total population, $\mathrm{S}_{\mathrm{v}}$ as vaccinated susceptible, $\mathrm{S}_{\mathrm{T}}$ as unvaccinated susceptible, I , infected, $\mathrm{R}$ as recovered, $\mathrm{c}$ as vaccination rate parameter, $\pi$ as birth rate parameter, $\beta_{\mathrm{v}}$ as transmission rate parameter of vaccinated susceptible, $\beta_{\mathrm{T}}$ as transmission rate parameter of unvaccinated susceptible, $\mu$ as natural mortality rate parameter, $\gamma$ as the transfer rate of population from recovered to be susceptible, $\mu_{\mathrm{T}}$ as parameter of death rate due to TB, $v$ as recovery rate parameter, and $\tau$ as period recovery.

The model can be simplified by assuming the following fractions

$$
w=\frac{S_{V}}{N}, x=\frac{S_{T}}{N}, y=\frac{I}{N}, z=\frac{R}{N}
$$

Thus, the model can be simplified as follows

$$
\begin{aligned}
& \frac{d w}{d t}=c \pi+\gamma z-\beta_{V} x y-\mu w \\
& \frac{d x}{d t}=(1-c) \pi-\beta_{T} x y-\mu x \\
& \frac{d y}{d t}=\left(\beta_{V}+\beta_{T}\right) x y-\mu y-\vartheta y(t-\tau)(7) \\
& \frac{d z}{d t}=\vartheta y(t-\tau)-(\mu+\gamma) z
\end{aligned}
$$


Here, the time delay varible $\mathrm{y}(\mathrm{t}-\tau)$ is expanded by Taylor series in form $y(t)-\tau \frac{d y}{d t}$. The SIR model can be written as

$$
\begin{aligned}
& \frac{d w}{d t}=c \pi+\gamma z-\beta_{V} x y-\mu w \\
& \frac{d x}{d t}=(1-c) \pi-\beta_{T} x y-\mu x \\
& \frac{d y}{d t}=\left(\beta_{V}+\beta_{T}\right) x y-\mu y-\vartheta\left(y(t)-\tau \frac{d y}{d t}\right) \\
& \frac{d z}{d t}=\vartheta\left(y(t)-\tau \frac{d y}{d t}\right)-(\mu+\gamma) z
\end{aligned}
$$

\section{Runge-Kutta Method}

Fourth order Runge Kutta Methodis the best method for solving system of differential equations. The following formula normally used is written as

Where

$$
y_{i+1}=y_{i}+\frac{1}{6}\left(k_{1}+2 k_{2}+2 k_{3}+k_{4}\right)
$$

$$
\begin{aligned}
& k_{1}=f\left(x_{i}, y_{i}\right) \\
& k_{2}=f\left(x_{i}+\frac{1}{2} h, y_{i}+\frac{1}{2} k_{1} h\right) \\
& k_{2}=f\left(x_{i}+\frac{1}{2} h, y_{i}+\frac{1}{2} k_{2} h\right) \\
& k_{4}=f\left(x_{i}+h, y_{i}+k_{3} h\right)
\end{aligned}
$$

To overcome the dificulty in solving delay form, the delay form i.e.y $(\mathrm{t}-\tau)$ changed toy $(t)+$ $\tau \frac{d y}{d t}$ which was proposed by Toaha (2009). The $y(t)+\tau \frac{d y}{d t}$ was obtaind by Taylor series.

\section{Result And Discussion}

Several investigations have done for SIR model of Tuberculosis with time delay in this paper. This model is suitable for the Medan City. Some parameters are taken from department of Health. The parameter is known as $c:=005, \pi=0.03, \gamma:=0.067, \beta_{\mathrm{V}}=0.1, \beta_{\mathrm{T}}=0.675, \mu:=0.03$, $\mu_{\mathrm{T}}=0.032, \vartheta=0.7389$ The initial populations in probability are

$w(0)=\frac{25400}{2229408} \quad, x(0)=2080288 / 2229408, y(0)=92470 / 2229408, z(0)=$ $31250 / 2229408$

Reported by department of health of medan city. The simulation was carried out using MAPLE by adopted data of Tuberculosis cases in theMedan city.

Behaviour dynamic of SIR model without delay time can be seen from figure 1. 


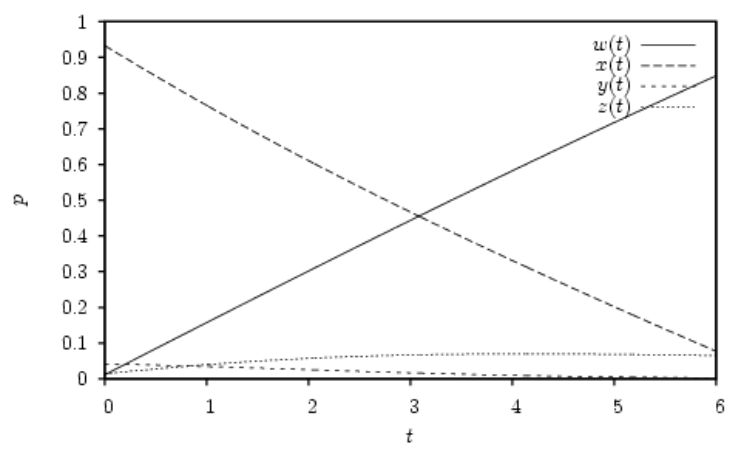

Figure 1 Dynamic behavior of SIR model of Tuberculosis in Medan City

Here, $\mathrm{x}$-axis is time (months) and the $\mathrm{y}$-axis is the probability of SIR model. Above results showed that probability of vaccinated susciptible increased sharply, whereas unvaccinated susciptible droped dramatiaclly tend to x-axis. For probability of invection, decreased slightly tond to horizontal axis, it means, by this model, infection population will be small, while recovered population increase slowly because, number of infection also slight. The following figure showeddynamical result of SIR with various time delays which were described in Figure 2.

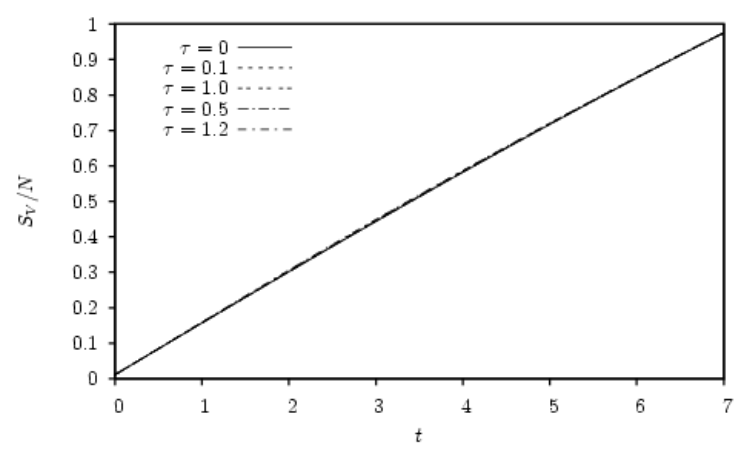

(a)

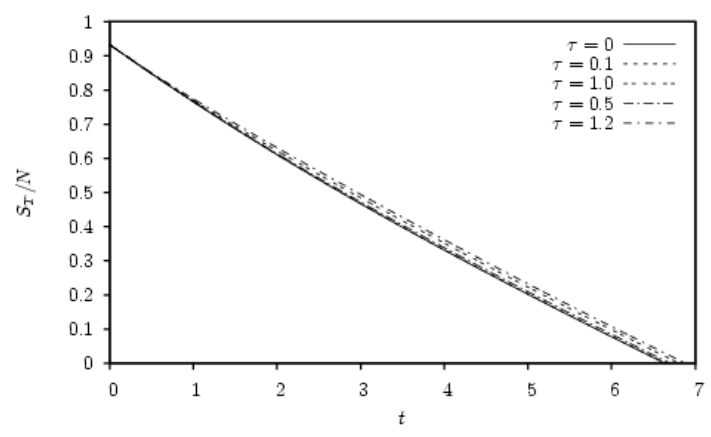


(b)



(c)

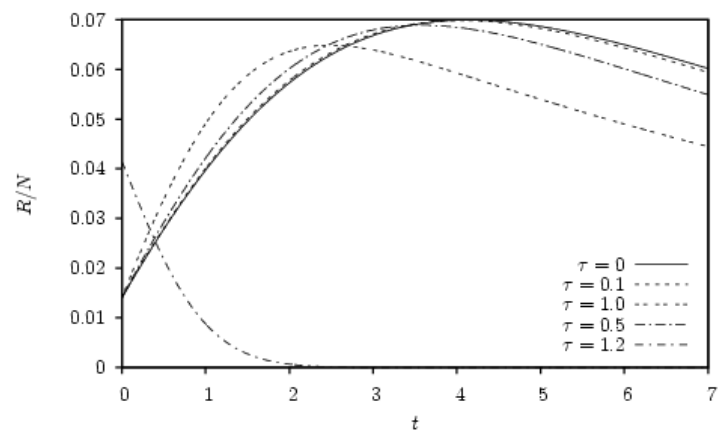

(d)

Figure 2 Graphics of Probability of all variables with Time Delay $\tau=0.1,0.5,1.0$ and $\tau=1.2$ and without time delay.

Figure 2 was devided by four time delay value $(\tau):$ (a) for $\tau=0.1,0.5,1.0$ and $\tau=1.2$, impact of time delay is small. Probability of sisceptible without and with time delay almost same. (b) for different $\tau$ was given, the impact of time delay also small to susciptible population. (c) the impact of time delay is to big. By time delay, population of infection drop sharply close to $\mathrm{x}$ axis, as long the time delay, infected population getting smaller. (d) the last graphic showed that there is no impact of $\tau$ to development of recovery population.

\section{Conclusions}

Numerical solution of SIR with delay time has been obtained. Some parameters are taken from department of Health. The parameter is known as $c:=005, \uparrow \pi=0.03, \gamma:=0.333, \beta_{\mathrm{v}}=0.1$, 
$\beta_{\mathrm{T}}=0.675, \mu:=0.03, \mu_{\mathrm{T}}=0.032, \vartheta=0.37$ The initial populations in probability are $w(0)=$ $\frac{25400}{2229408}, x(0)=2080288 / 2229408, y(0)=92470 / 2229408, z(0)=31250 / 2229408$

reported by department ofhealth of medan city. Calculation for numerical method used fourth order Runge-kutta Method and assisted by MAPLE. software . Time delay $\tau$, i.e. $\tau=0.1,0.5,1.0$ and $\tau=1.2$, very gave big impact to number of infected population. The population of infection drop sharply close to $\mathrm{x}$-axis, as long the time delay, infected population getting smaller otherwise no impact of time delay to other populations. RK method can be an alternative method for solving another system of delay differential equation.

Acknowledgments. The heading should be treated as a $3^{\text {rd }}$ level heading and should not be assigned a numberThe financial support received from BOPTN UNIMED is gratefully acknowledged.

\section{References}

[1]Dani, 2017, Sebulan, 1.000 Orang Tercatat Suspect TB, Koran Analisa online, http://harian.analisadaily.com/kota/news/sebulan-1000-orang-tercatat-suspect-tb/471140/2017/12/17 access date 17 Desember 2017

[2]Putra, TMP 2018, Ruang Publik Rentan Jadi Tempat Penularan Tuberkulosis, Republika online, http://nasional.republika.co.id/berita/nasional/jabodetabek-nasional/18/03/23/p61wyq284-ruangpubik-rentan-jadi-tempat-penularan-tuberkulosis, access date 23 Maret 2018

[3]Iskandar, T., Chaniago, N.A., Munzir, S.Halfiani, V\&Ramli, M., 2017.Mathematical Model of Tuberculosis Epidemic with Recovery Time Delay AIP Conference Proceedings 1913, 020021

[4]Islam, M.A.: A Comparative Study on Numerical Solutions of Initial Value Problems(IVP) for Ordinary Differential Equations (ODE) with Euler and Runge Kutta Methods, American Journal of Computational Mathematics, 5 (3), 93-404 (2015)

[5]Majid, Z.A.: Solving Directly Two Point Non Linear Boundary Value Problems Using Direct Adams Moulton Method, Journal ofMathematics and Statistics, 7 (2): 124-128(2011)

[6]Seong, H.Y.,Majid, Z.A. \& Ismail, F., Solving Second-Order Delay Differential Equations by Direct Adams-Moulton Method, MathematicalProblemsinEngineering, Vol. 2013,ArticleID261240

[7]Tat,C.K., Majid, Z.A., Suleiman, M.\& Senu, N.: Solving Linear Two-Point Boundary Value Problems by Direct Adams Moulton Method AppliedMathematical Sciences, Vol. 6, 2012, no. 99, $4921-4929$ (2012)

[8]Toaha, S.: Kestabilan Model Populasi Mangsa Pemangsa dengan Pemanenan dan Waktu Tunda Melalui Pendekatan Bentuk, $y(t)+\tau \frac{d y}{d t}$.Jurnal Mathematik, Statistik and Komputasi, Vol. 5, No.2, 76-85(2009)

[9]Zwerling, A., Shrestha, S., and Dowdy, D.W.: Mathematical Modelling and Tuberculosis: Advances in Diagnostics and Novel Therapies, Advance in Medicine, Vol. 2015, Article ID 907267 (2015) 